\title{
Determination of harmful locusts and their distribution in transborder territories of Uzbekistan using geographic information system
}

\author{
Nodirbek Tufliev ${ }^{1, *}$ and Sherzod Akhmedjanov ${ }^{1}$ \\ ${ }^{1}$ Tashkent State Agrarian University, University street, 2, Tashkent province, 100140 Uzbekistan
}

\begin{abstract}
Diversity of natural climatic conditions in Central Asia leads to the mass development and spread of cross-border pests, especially locusts, in these provinces. This requires monitoring studies to determine the species composition of endangered locusts that migrate from one state to another in transboundary areas and among them the most major pest species that pose a threat to agricultural crops. Therefore, this article identifies the species composition of locusts found in the border areas of Uzbekistan with neighboring republics of Tajikistan, Kyrgyzstan and Turkmenistan, including harmful species. The results of the use of geographic information system (GIS) technologies in monitoring the spread of locusts in the cross-border areas of Surkhandarya, Kashkadarya, Jizzakh and Namangan provinces are presented.
\end{abstract}

\section{Introduction}

It is known that Uzbekistan borders with almost all Central Asian countries. The ecological and geographical location of the border areas of the Republic with the Central Asian states of Kazakhstan, Kyrgyzstan, Turkmenistan and Tajikistan is the same for both border states $[1,4,5]$. This poses a risk of the spread and reproduction of harmful locusts in all neighboring republics, including Uzbekistan, and the extinction of harmful locusts in the territory of our Republic and damage to agricultural crops, or vice versa. This is often the case in cross-border areas with neighboring countries.

Harmful locusts require constant attention from industry experts around the world. Moroccan, Italian and Asian locusts, which live in Central Asia and the Caucasus alone, can damage more than 25 million hectares of pastures and crops if not taken in a timely manner. As a result, more than 20 million people are at risk of being directly deprived of food $[1-3,9]$.

The first data on locust pests as a cross-border pest were initially listed in the FAO's data on Egyptian state records as a cause of famine by cultivating crops [2]

As mentioned above, the distribution area of the Desert locust (Schistocerca gregaria Forsk) is one of the 12 most dangerous species of locust pests in the world, with a

* Corresponding author: nodirbek.tufliev@yandex.com 
simultaneous distribution in more than a dozen African countries. This locust species is endemic to the African continent alone, with swarms spreading up to 30 million $\mathrm{km} 2$, causing damage to crops in 60 states. This was first observed in the last 20 years - in 20032005 in the countries of North and North-West Africa. As a result, an annual crop of 8 million people was lost and more than 13 million hectares were treated with locust control chemicals [6-8].

After experiencing such development and loss of locusts several times, an Early Locust Prevention System (ELPS) was developed and implemented in the Central African Republics [3, 11].

The Desert Locust Control System has cost \$11.5 million to set up in Central Africa and has cost $\$ 7$ million to operate over 10 years. During this period, the system prevented the cross-border spread of desert locusts in more than 30 countries and saved about $\$ 390$ million in damage $[7-9,13]$.

The total increase in desert locusts in the first quarter of 2020, according to the FAO, caused a total of $\$ 138$ million in damage in North African countries. In the context of the global pandemic, it has not been possible to collect such a large amount of aid from countries, and a total of $\$ 33$ million has been allocated by donors [11].

Scattered desert locusts in Africa can spread from 40 million to 80 million locust imaginations per square kilometer. But a single swarm of locusts can have more than 100 million locusts. One ton of locusts is a gala of about 500,000 locusts that can eat 10 elephants or 25 camels or 200 tons of plant that can be consumed by 2,500 people a day. One swarm of locusts in Kenya covers an area of 2,400 km2 and is home to 200 billion people. consisting of locusts and ate 400,000 tons of plant every 24 hours, which could be food for 84 million people [10, 12].

The Schistocerca cancellata locust, which is endemic to the South American continent, belongs to the Cyrtacanthacridinae family and, from solitary survival in 2020 to the swarmforming phase, is widespread in Brazil, Argentina and Uruguay. A swarm of locusts spread 40 million locusts per square kilometer, destroying agriculture by eating green mass that would feed 35,000 people and 2,000 head of livestock per day [14].

There has also been a general increase in locusts on the Australian continent, with three species of locusts being identified as swarm-forming locusts: the Australian locust (Chortoicetes terminifera), the long-necked locust (Austracris guttulosa) and the Asian locust (Locusta migratoria). Of these locust species, the Australian locust is the most dangerous, with a massive increase between 1999 and 2004 that caused \$25 million in damage to Australian agriculture [10-12].

According to the U.S. Department of Agriculture, locusts, nightingales, and rodent mammals are listed as cross-border pests. The dynamics of development of this group of people causes transboundary problems in some years, as a result of over-expansion of the distribution area to millions of hectares, spreading in at least 5 countries at the same time [13].

The diversity of natural climatic conditions in Central Asia leads to the mass development and spread of cross-border pests, especially locusts, in these provinces. This requires monitoring studies to determine the species composition of endangered locusts that migrate from one state to another in transboundary areas and among them the most major pest species that pose a threat to agricultural crops.

\section{Materials and methods}

Our initial research was conducted in Rudaki, Shahrituz, Nosiri Khisrav, Khorasan, Kabadiyon districts of the neighboring Republic of Tajikistan, Khatlon province and adjacent districts of Uzun, Kumkurgan, Shurchi, Jarkurgan, Termez, Denau districts of 
Surkhandarya province. In addition, we conducted research to study the species composition of locusts found in neutral areas between the banks of the Kofirnigon River, which flows through the border area of both countries.

It is known that the total length of the border area of Surkhandarya province with the Republic of Tajikistan is $343 \mathrm{~km}$. The monitoring revealed $195 \mathrm{~km}$ of border areas where locusts could pass and spread. Based on our observations, it was studied that there are differences in the landscapes of the two countries, although the soil climatic conditions are the same $[1,2]$.

In 2018, there was little rainfall and drought in the territory of Uzbekistan, and in 20192020, the weather in Surkhandarya province was rainy and seasonal ephemeral-ephemeroid plants were well developed [2,3].

According to the results of our research, 20 species of locusts have been found in the border areas of both countries, and these locusts are rare, moderate and widespread [1-3].

\section{Results and discussion}

According to the monitoring results, the Moroccan locust (Dociostaurus maroccanus Thunb) was widespread in the border areas of both countries, with an average number of 100-200 species per $1 \mathrm{~m}^{2}$ in both countries. Small crustaceans (D kraussi nigrogeniculatus L) are widespread in the territory of the Republic of Tajikistan and their number averages 15-25 per $1 \mathrm{~m}^{2}$. The locust (C turanicus Tarb) was widespread in Uzbekistan and numbered $10-15$ in $1 \mathrm{~m}^{2}$. It was noted that the drought in 2018 led to a decrease in the number of harmful locusts in 2019.

D. kraussi Ingen., Ramburiella turcomana F.-W., Oedaleus decorus Germ., Sphingoderus carinatus Sauss., Calliptamus italicus L., C. barbarus Costa., Tropidopola turanica Uv., Acrotylus insubricus insubricus Walk., D. tartarus Stchelk., Duroniella kalmyka Ad., Sphingonotus maculates Uv., Pergodera armata F.d.W., Sphingoderus carinatus Sauss., Anacridium aegipitium L., Pyrgomorpha bispinosa deserti B.-Bien. Serg., Leptopternis gracilis Ev., and L. iliensis Uv. species were studied to be moderately distributed in the border areas of both countries (Table 1).

Table 1. Species composition of locusts found in Surkhandarya province and the border areas with Khatlon province (2018-2020).

\begin{tabular}{|c|c|c|c|}
\hline \multirow{2}{*}{\multicolumn{2}{|c|}{ Locust species }} & \multicolumn{2}{|c|}{ Locust species distributed in transbordered areas } \\
\hline & & $\begin{array}{l}\text { Surkhandarya } \\
\text { province (UZ) }\end{array}$ & Khatlon province (TJ) \\
\hline \multicolumn{4}{|c|}{ Acrididae family } \\
\hline 1. & $\begin{array}{c}\text { Dociostaurus maroccanus } \\
\text { Thunb. }\end{array}$ & (h) +++ & (h) +++ \\
\hline 2. & D. kraussi Ingen. & + & ++ \\
\hline 3. & D. kraussi nigrogeniculatus $\mathrm{L}$. & ++ & +++ \\
\hline 4. & D. tartarus Stchelk. & + & + \\
\hline 5. & Duroniella kalmyka Ad. & + & + \\
\hline 6. & Ramburiella turcomana F.-W. & + & ++ \\
\hline 7. & Oedaleus decorus Germ. & ++ & ++ \\
\hline 8. & O. senegalensis $\mathrm{Kr}$. & + & + \\
\hline 9. & Sphingonotus maculates Uv. & + & + \\
\hline 10. & Pyrgodera armata F.d.W. & + & + \\
\hline 11. & Sphingoderus carinatus Sauss. & & + \\
\hline
\end{tabular}




\begin{tabular}{|c|c|c|c|}
\hline 12. & Calliptamus italicus $\mathrm{L}$. & ++ & + \\
\hline 13. & C. turanicus Tarb. & ++ & ++ \\
\hline 14. & C. barbarus Costa. & ++ & ++ \\
\hline 15. & Anacridium aegipitium $\mathrm{L}$. & + & ++ \\
\hline 16. & Tropidopola turanica Uv. & ++ & + \\
\hline 17. & Pyrgomorpha bispinosa deserti \\
\hline 18. & Bcrotylus insubricus Walk. & ++ & + \\
\hline 19. & Leptopternis gracilis Ev. & + & + \\
\hline 20. & L. iliensis Uv. & + & + \\
\hline
\end{tabular}

Note: + - less observed; ++ - often observable; +++ - widely observed; and $(h)$ - heaps.

In our studies in the cross-border areas of both countries, it was noted that the main dominant species is the Moroccan locust (Dociostaurus maroccanus Thunb), which has a high risk of migration from one country to another and damages agricultural crops.

In 2019-2020, scientific research was conducted in the cross-border areas of Dehkanabad, Guzar, Nishan districts of Kashkadarya province, bordering with the State, Great Safarmurat districts of Lebap province of neighboring Turkmenistan. The area bordering Kashkadarya province and Lebap province of Turkmenistan is about $135 \mathrm{~km}$, of which the presence of favorable locusts for the development and reproduction of harmful locusts in the cross-border areas between the districts and provinces above was studied.

As a result of locusts flying across the border with Lebap province of Turkmenistan, an average of 10-15,000 hectares of locusts have to be chemically treated each year. Taking into account these problems, we conducted a study to determine the species composition of locusts found in the border areas with Kashkadarya province and Lebap province and the main harmful dominant species between them (Table 2).

Table 2. Species composition of locusts found in the border areas of Kashkadarya province and Lebap province (2019-2020).

\begin{tabular}{|c|c|c|c|}
\hline & \multirow{2}{*}{ Locust species } & \multicolumn{2}{|c|}{ Locust species distributed in transbordered areas } \\
\hline & & $\begin{array}{c}\text { Kashkadarya province } \\
\text { (UZ) }\end{array}$ & Lebap province (TM) \\
\hline \multicolumn{4}{|c|}{ Acrididae family } \\
\hline 1. & Dericorys albidula Serv. & + & ++ \\
\hline 2. & D. tibialis Pall. & + & + \\
\hline 3. & Tropidopola turanica Uv. & + & + \\
\hline 4. & Calliptamus turanicus Tarb. & ++ & +++ \\
\hline 5. & C. barbarus F.-W. & + & + \\
\hline 6. & Heteracris adspersus Redt. & ++ & + \\
\hline 7. & Duroniella kalmyka Ad. & + & + \\
\hline 8. & D. gracilis Uv. & + & \\
\hline 9. & Ramburiella turcomana F.-W. & + & + \\
\hline 10. & Dociostaurus maroccanus Thunb. & (h) +++ & (h) +++ \\
\hline 11. & D. kraussi Ingen. & + & ++ \\
\hline 12. & D. tartarus Stchelk. & + & + \\
\hline 13. & Oedaleus decorus Germ. & + & ++ \\
\hline 14. & Mioscirtus wagneri Sauss. & + & + \\
\hline
\end{tabular}




\begin{tabular}{|r|c|c|c|}
\hline 15. & Acrotylus insubricus Walk. & + & + \\
\hline 16. & Sphingonotus maculatus Uv. & + & ++ \\
\hline 17. & S. rubescens Walk. & + & + \\
\hline 18. & S. satrapes Sauss. & + & + \\
\hline 19. & Sphingoderus carinatus Sauss. & + & + \\
\hline 20. & Hyalorrhipis clause Kitt. & ++ & + \\
\hline 21. & Leptopternis gracilis Ev. & + & ++ \\
\hline 22. & Pergomdera armata F. -W. & + & + \\
\hline 23. & Pezotmethis tartarus tartarus Sauss. & + & + \\
\hline
\end{tabular}

Note: + - less observed; ++ - often observable; +++ - widely observed; and $(h)$ - heaps.

According to the results of the monitoring, the seasonal Targobchigay River, which flows between the border areas of the two countries at an altitude of 800-1000 meters above sea level, begins to flow from the Chak-Chak ridge. Kuhitang is filled with added water from the mountain range and flows seasonally.

It is known that the river flows through the transboundary territory of both countries, and its location allows the Moroccan locust (Dociostaurus maroccanus Thunb), which spreads in the range of 800-1200 meters above sea level, to form a swarm. It was noted that this type of locust is the main species of locusts for both countries, especially in the Dehkanabad and Guzar districts of Kashkadarya province, which cause damage to existing pasture plants and agricultural crops.

The study also found that of the 23 species of locusts found in the transboundary provinces of Uzbekistan and Turkmenistan, the number of locusts (Calliptamus turanicus Tarb) has increased in recent years, and their damage is increasing. In particular, the proliferation of locusts in the border areas with neighboring Turkmenistan, the fact that after the end of the locust control season, adult locusts fly to Kashkadarya province, the damage to this species of locusts is growing every year.

It was also noted that locusts such as Dericorys albidula Serv, Sphingonotus locust (Sphingonotus maculatus Uv) are moderately distributed in the transboundary areas of neighboring Lebap province. If this locust is not controlled in a timely manner, it will cause significant damage to saxaul and other agricultural crops in the border areas of Uzbekistan.

The remaining species of locusts were found in small numbers in the transboundary areas of both countries, ie their number did not exceed an average of 1-2 per $1 \mathrm{~m}^{2}$.

Our further research was conducted to study the species of locusts in the transboundary areas of the Sughd province of the Republic of Tajikistan, Jizzakh province, bordering on Zafarabad district, Yangiabad district and to identify the main dominant species among them.

It is known that the border area between Jizzakh and Sughd provinces is more than 60 $\mathrm{km}$, and in the cross-border area every year in Balandchakir and Khojameshkentsoy areas of Yangiabad district of Jizzakh province an additional 6-8 thousand hectares are chemically treated against locusts.

In our study of locusts in the transboundary areas of these two countries and the species that pose a threat to the main agricultural crops between them, 22 species of locusts belonging to the family Acrididae and 3 species of beetles belonging to the family Tettigonidae are found in low, medium and large numbers (Table 3). 
Table 3. Species composition of locusts found in Yangiabad district of Jizzakh province and in the border areas of Zafarabad district in Sughd province (2019-2020)

\begin{tabular}{|c|c|c|c|c|}
\hline & \multirow{2}{*}{ Locust species } & \multicolumn{3}{|c|}{ Locust species distributed in transbordered areas } \\
\hline & & $\begin{array}{c}\text { Yangiabad district, Jizzakh } \\
\text { province (UZ) }\end{array}$ & $\begin{array}{c}\text { Zafarabad district, Sugc } \\
\text { province }(\mathrm{TJ})\end{array}$ & \\
\hline \multicolumn{5}{|c|}{ Acrididae family } \\
\hline 1. & $\begin{array}{l}\text { Dociostaurus maroccanus } \\
\text { Thunb. }\end{array}$ & (h) ++ & \multicolumn{2}{|l|}{ (h) +++} \\
\hline 2. & Calliptamus turanicus Tarb. & ++ & \multicolumn{2}{|l|}{+++} \\
\hline 3. & C. italicus $\mathrm{L}$. & (h)+ & \multicolumn{2}{|l|}{ (h)++ } \\
\hline 4. & C. barbarus F.-W. & + & \multicolumn{2}{|l|}{+} \\
\hline 5. & Oedaleus decorus Germ. & ++ & \multicolumn{2}{|l|}{++} \\
\hline 6. & Locusta migratoria $\mathrm{L}$ & (h)++ & \multicolumn{2}{|l|}{ (h)++ } \\
\hline 7. & $\begin{array}{c}\text { Pezotmethis tartarus tartarus } \\
\text { Sauss. }\end{array}$ & + & \multicolumn{2}{|l|}{+} \\
\hline 8. & Ramburiella turcomana $\mathrm{F} . \mathrm{-W}$. & ++ & \multicolumn{2}{|l|}{++} \\
\hline 9. & D. kraussi Ingen. & + & \multicolumn{2}{|l|}{++} \\
\hline 10 & Conophyma sokolowi Zub. & + & \multicolumn{2}{|l|}{+} \\
\hline 11 & Pergomdera armata $\mathrm{F} .-\mathrm{W}$. & + & \multicolumn{2}{|l|}{+} \\
\hline 12 & Tropidopola turanica Uv. & + & \multicolumn{2}{|l|}{+} \\
\hline 13 & Hyalorrhipis clause Kitt. & + & \multicolumn{2}{|l|}{+} \\
\hline 14 & Leptopternis gracilis Ev. & ++ & \multicolumn{2}{|l|}{++} \\
\hline 15 & Anagridium aegyptium L. & ++ & \multicolumn{2}{|l|}{++} \\
\hline 16 & Heteracris littoralis $\mathrm{Br} . \mathrm{W}$. & + & \multicolumn{2}{|l|}{+} \\
\hline 17 & Duroniella kalmyka Ad. & + & \multicolumn{2}{|l|}{+} \\
\hline 18 & Oedipoda miniata Pall. & + & \multicolumn{2}{|l|}{+} \\
\hline 19 & Mioscirtus wagneri Sauss. & + & \multicolumn{2}{|l|}{+} \\
\hline 20 & Sphingonotus maculatus Uv. & + & \multicolumn{2}{|l|}{++} \\
\hline 21 & S. satrapes Sauss. & + & \multicolumn{2}{|l|}{+} \\
\hline 22 & Sphingoderus carinatus Sauss. & + & \multicolumn{2}{|l|}{+} \\
\hline \multicolumn{5}{|c|}{ Tettigonidae family } \\
\hline 1. & Tettigonia viridissima $\mathrm{L}$. & \multicolumn{2}{|c|}{++} & $\begin{array}{l}+ \\
+\end{array}$ \\
\hline 2. & T. caudata Charp. & \multicolumn{2}{|c|}{++} & $\begin{array}{l}+ \\
+\end{array}$ \\
\hline 3. & Decticus verrucivorus L. & \multicolumn{2}{|c|}{+} & + \\
\hline
\end{tabular}

Note: + - less observed; ++ - often observable; +++ - widely observed; and (h) - heaps.

In our study, Moroccan locusts (Dociostaurus maroccanus Thunb), Italian locusts (Calliptamus italicus L), Turan locusts (C turanicus Tarb) and Asian locusts were found in the transboundary areas of Yangiabad district and Zafarabad district. It is interesting to note that this species of locust is widespread in the territory of the neighboring Republic of Tajikistan, Zafarabad district.

Considering that it takes at least 8-12 years for this type of locust to move from a nonswarming habitat to a swarming swarm, it can be concluded that the neighboring Republic 
of Tajikistan has not carried out chemical treatment against harmful locusts in these areas in recent years.

Every year, the Republic of Uzbekistan conducts timely control of locust infestations. During the monitoring, it was noted that due to limited financial resources in the Zafarabad district of the neighboring Republic of Tajikistan, there is no timely chemical control of this type of locust.

It was also noted that there are problems in the fight against harmful locusts, as the main area where the locusts are spread and multiply is in the form of snakes on the border area of both countries.

As a result, cotton, cereals, soybeans, melons and other crops planted in the Yangiabad district of Jizzakh province are damaged almost every year, in whole or in part, in some years by flying across the border of the neighboring Republic of Tajikistan. This is also due to the differences in the bioecology of the development of harmful locusts in the transboundary province of both countries, while in April-May there is a risk of Moroccan locusts, in May-June-July Turan, Italian locusts.

Green (Tettigonia viridissima L) and gray (T caudata Charp) rodents belonging to the subfamily long-whiskered are also moderately distributed in the territory of Uzbekistan, while they are moderately or massively distributed in the territory of the neighboring Republic. It has been studied that these irons also damage the crops in orchards planted in some years in Yangiabad district.

Locust species found in the transboundary areas of Sughd province, Zafarabad district and Yangiabad district of Jizzakh province were found to be as followings: C. barbarus F.W., Oedaleus decorus Germ., Pezotmethis tartarus tartarus Sauss., Ramburiella turcomana F.-W., D. kraussi Ingen., Ramburiella turcomana F.-W., Conophyma sokolowi Zub., Pergomdera armata F. -W., Tropidopola turanica Uv., Hyalorrhipis clause Kitt., Leptopternis gracilis Ev., Anagridium aegyptium L., Heteracris littoralis Br.-W., Duroniella kalmyka Ad., Oedipoda miniata Pall., Mioscirtus wagneri Sauss., Sphingonotus maculatus Uv., S. satrapes Sauss., Sphingoderus carinatus Sauss., and Decticus verrucivorus $\mathrm{L}$. species with low or moderate numbers, and their number was less than the economically harmful quantity criteria and did not have the ability to damage crops.

Border area of Jalalabad province, Olaboka, Karavan, Aksu, Kyzyljar districts of the Kyrgyz Republic and Uychi district of Namangan province $17 \mathrm{~km}$, Chartak district $26 \mathrm{~km}$, Uchkurgan district $38 \mathrm{~km}$, Kosonsoy district $41 \mathrm{~km}$, Chust district $46 \mathrm{~km}$, and Yangikurgan district $79 \mathrm{~km} 247 \mathrm{~km}$.

In our study of the species composition of harmful locusts in the border areas of Namangan province, neighboring Kyrgyzstan, Jalalabad province, it was noted that 24 species of locusts are rare, moderate and widespread (Table 4). 
Table 4. Species composition of locusts found in the border areas of Namangan province, the Kyrgyz Republic, Jalalabad province (2018-2019)

\begin{tabular}{|c|c|c|}
\hline \multirow[b]{2}{*}{ Locust species } & \multicolumn{2}{|c|}{ Locust species distributed in transbordered areas } \\
\hline & $\begin{array}{c}\text { Transboundary districts } \\
\text { of Namangan province } \\
\text { (UZ) }\end{array}$ & $\begin{array}{c}\text { Transboundary } \\
\text { districts of Jalalabad } \\
\text { province (KG) }\end{array}$ \\
\hline \multicolumn{3}{|c|}{ Acrididae family } \\
\hline Dociostaurus maroccanus Thunb. & ++ & ++ \\
\hline Calliptamus italicus L. & ++ & +++ \\
\hline C. turanicus Tarb. & ++ & +++ \\
\hline C. barbarus Costa. & ++ & ++ \\
\hline D. kraussi Ingen. & + & + \\
\hline D. kraussi nigrogeniculatus L. & + & + \\
\hline Pezotmethis tartarus Sauss. & ++ & ++ \\
\hline Duroniella kalmyka Ad. & ++ & ++ \\
\hline D. gracilis Uv. & + & + \\
\hline Ramburiella turcomana F.-W. & + & + \\
\hline Oedaleus decorus Germ. & ++ & ++ \\
\hline O. senegalensis $\mathrm{Kr}$. & + & + \\
\hline Sphingonotus maculates Uv. & ++ & ++ \\
\hline S. rubescens Walk. & ++ & ++ \\
\hline Pyrgodera armata F.d.W. & ++ & ++ \\
\hline Sphingoderus carinatus Sauss. & ++ & ++ \\
\hline Anacridium aegipitium L. & + & + \\
\hline Tropidopola turanica Uv. & ++ & ++ \\
\hline Heteracris adspersus Redt. & ++ & ++ \\
\hline H.littoralis Br.-W. & + & + \\
\hline $\begin{array}{c}\text { Pyrgomorpha bispinosa deserti B.- } \\
\text { Bien. Serg. }\end{array}$ & ++ & ++ \\
\hline $\begin{array}{c}\text { Acrotylus insubricus insubricus } \\
\text { Walk. }\end{array}$ & + & + \\
\hline Leptopternis gracilis Ev. & + & + \\
\hline Thrinchus desertus B.-Bien. & + & + \\
\hline
\end{tabular}

Note: + - less observed; ++ - often observable; +++ - widely observed; and $(h)$ - heaps.

In our research, it was found that Dociostaurus maroccanus Thunb - Moroccan locust, Calliptamus italicus L - Italian locust, C turanicus Tarb - locust (Turon) locust are moderately distributed in the transboundary areas on the Uzbek side.

It was noted that there were no cases of mass extinction of locusts on agricultural lands due to the timely control of their locusts on the Uzbek side.

However, after the end of the season, the Dociostaurus maroccanus Thunb, the Calliptamus italicus L, the Italian locust, the C turanicus Tarb, the Turon locust, came from the neighboring Kyrgyz Republic were observed in 1993, 1998, 2001, 2007, 2009, 2011, and 2013.

Our observations in Namangan province, on the border with the Kyrgyz Republic, show that almost all areas are planted with agricultural crops and there are no open areas for the mass growth of locusts. 
It was found that locust species such as D. kraussi Ingen., D.kraussi nigrogeniculatus L., Pezotmethis tartarus Sauss., Duroniella kalmyka Ad., D. gracilis Uv., Ramburiella turcomana F.-W., Oedaleus decorus Germ., O. senegalensis Kr., Sphingonotus maculates Uv., S. rubescens Walk., Pyrgodera armata F.d.W., Sphingoderus carinatus Sauss., Anacridium aegipitium L., Tropidopola turanica Uv., Heteracris adspersus Redt., $H$. littoralis Br.-W., Pyrgomorpha bispinosa deserti B.-Bien. Serg., Acrotylus insubricus insubricus Walk., Leptopternis gracilis Ev., Thrinchus desertus B.-Bien., were prevalent in open hilly pastures only in the vicinity of the border, and that their numbers were low or moderate, and that their study was limited by the degree of damage to crops.

Taking into account this problem, we conducted a study on the mass reproduction of locusts in the border areas of Uzbekistan with neighboring countries, the identification of distribution centers using GIS based on the characteristics of locust development.

In the 21st century, Geographic Information System (GIS) technologies are being actively used. The use of GIS technology for the future of any industry will lead to its development [15-17]. The GIS system is widely used in agriculture in developed countries $[15,18-20]$. The use of the GIS system against pests allows, first of all, to determine the areas of distribution of insects, their area and visualize the area. Through such opportunities, the prediction of pests in agriculture using this system, the early detection of their damage, facilitates the possibility of determining control measures. As in other areas, we used Google.earth to identify locations where locusts are likely to spread in areas bordering neighboring countries.

The advantage of this system is that it is possible to determine the total area of locusts that can spread in the transboundary areas of neighboring countries, from which areas they can cross into our country using satellite imagery.

In the border areas of Surkhandarya province, locusts spread from 364 meters above sea level to 1,650 meters above sea level (a favorable place for the growth and development of Moroccan locusts) in Kumkurgan district alone, which includes mountains and foothills. It was studied that such areas mainly correspond to the territories of Uzun, Kumkurgan, Shurchi, Jarkurgan, Denov districts bordering on Khatlon, Tursunzoda, Shahrituz provinces of the Republic of Tajikistan. It was found that the area where locusts can spread in these pastures and the surrounding border areas is 570-980 meters above sea level. According to the monitoring results, the main breeding grounds and distribution areas of harmful locusts were studied and mapped on 83,487 hectares of land close to the border zones of pastures and adjacent mountain and foothill landscapes.

In the course of the study it was studied that in the territory of the Republic of Tajikistan in the areas bordering on Surkhandarya province of the Republic, in the mountains and foothills at an altitude of 326-1264 meters above sea level there are 38,864 hectares of pastures. In the Republic of Tajikistan, in the Khatlon province, 137,233 hectares of locust outbreaks were identified and mapped using the GIS (the territory of Uzbekistan is highlighted in pink, the territory of neighboring republics is highlighted in red) (Fig. 1).

As a result of monitoring and research conducted in Kashkadarya province, in Dehkanabad, Guzar, Nishan districts of the province, on a total area of 76,959 hectares bordering on Lebap province of Turkmenistan, there are areas with favorable conditions for the spread of locusts. In the Lebap province of Turkmenistan, on the border with Kashkadarya province, a total of 107,777 hectares of land were found to be conducive to the reproduction and spread of locusts, and these areas were cleared (Fig. 2).

Observations in Jizzakh province using GIS technologies have shown that locust infestation centers exist in the Yangiabad district of the province bordering the Sughd province of the Republic of Tajikistan. In this area, locusts can be spread on a total area of 2,168 hectares. In the Sughd province of the Republic of Tajikistan, there are foci of locust 
infestation on 3,540 hectares of land bordering the Yangiabad district of Jizzakh province (Fig. 3).

Observations by the GIS show that the territory of the Sughd province of the Republic of Tajikistan is up to $12 \mathrm{~km}$ in the territory of Jizzakh province, which does not differ from the natural climatic conditions of the border areas of Yangiabad district. The altitude in both countries is 768-1,226 meters above sea level. These data indicate that there are very favorable conditions for the development of locusts in the border area.
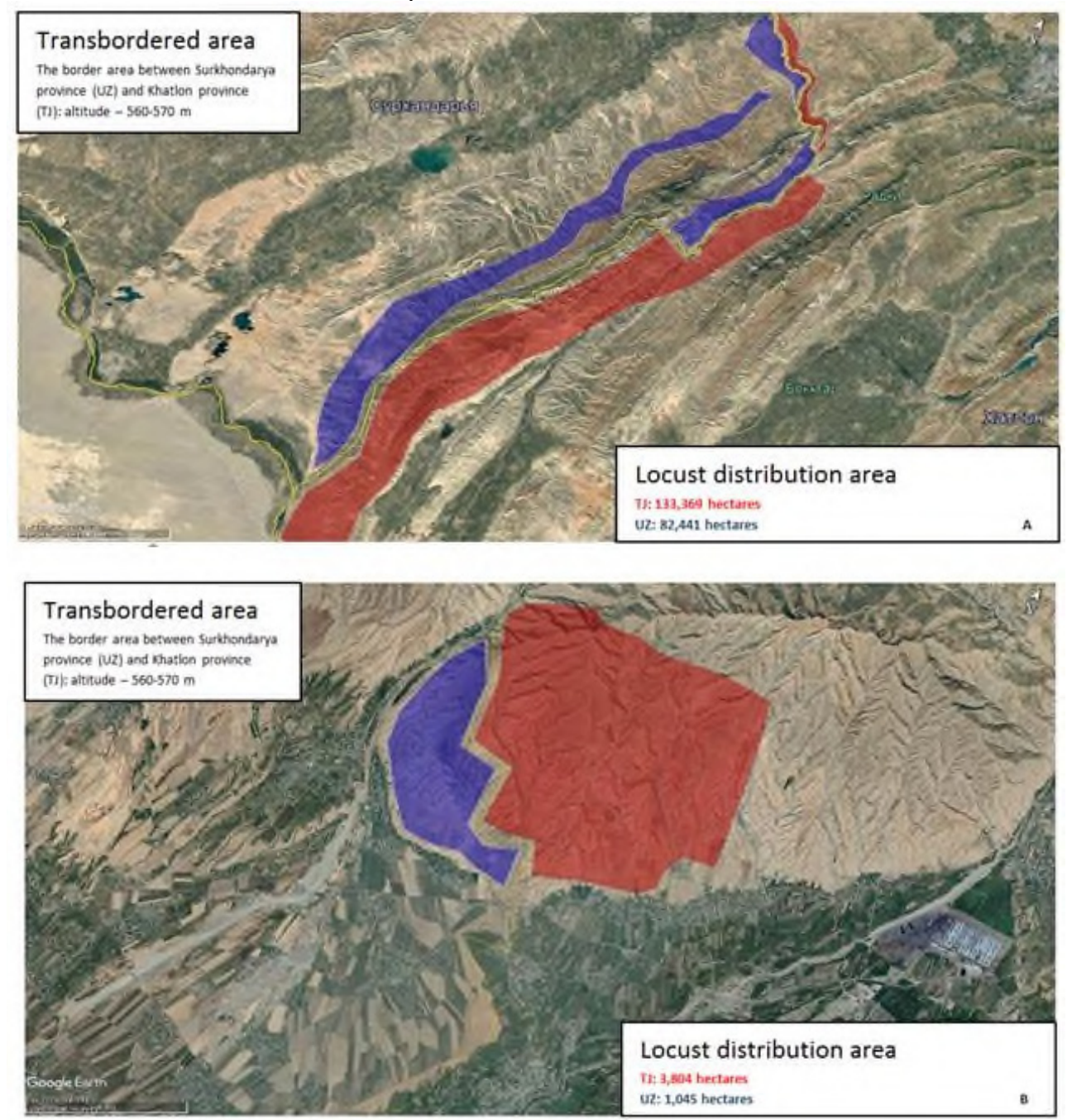

Fig. 1. Locust distribution in the border areas with Surkhandarya province of the Republic of Uzbekistan and Khatlon province of the Republic of Tajikistan (Photo by Google Earth using the GIS system). 


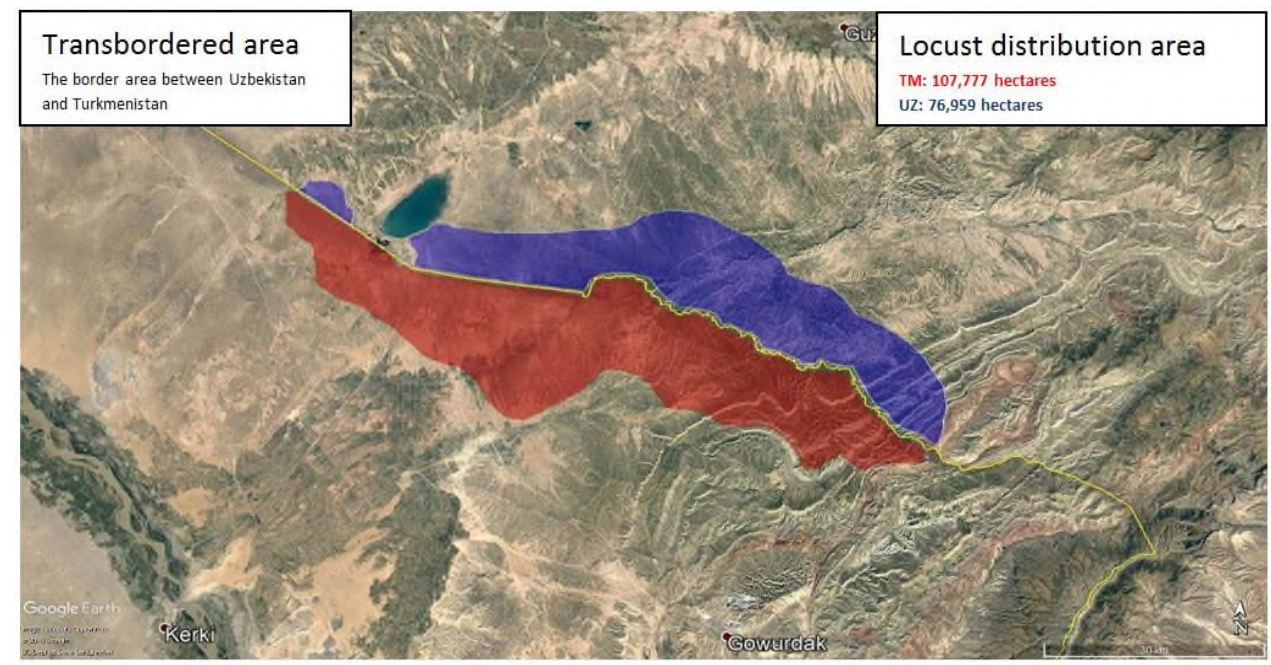

Fig. 2. Locust distribution in the border areas with Surkhandarya province of the Republic of Uzbekistan and Khatlon province of the Republic of Tajikistan (Photo by Google Earth using the GIS system).

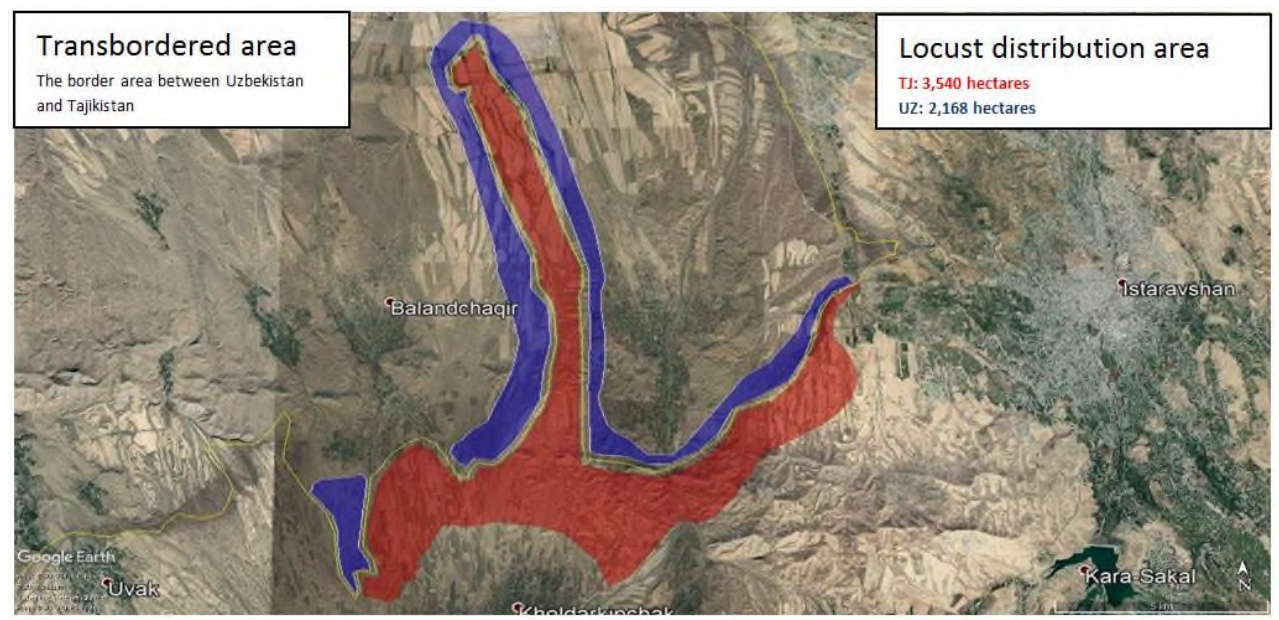

Fig. 3. Locust distribution areas in the border areas with Jizzakh province of the Republic of Uzbekistan, Yangiabad and Sughd province of the Republic of Tajikistan, Zafarabad district (photo by GIS system of Google Earth program).

According to the monitoring results in Namangan province, locust infestations were detected in the foothills of Uychi, Chartak, Chust districts of the province bordering on Jalalabad province of the Kyrgyz Republic at an altitude of 550-850 meters above sea level. As a result of scientific research, the presence of locust infestation centers on a total of 7,958 hectares of pastures in the territory of Namangan province was identified and identified (Fig. 4).

A study of the Jalalabad province of the Kyrgyz Republic and the border with Namangan province of the country revealed a total of 35,175 hectares of pastures where locusts can spread and marked them on the map with the help of GIS. 

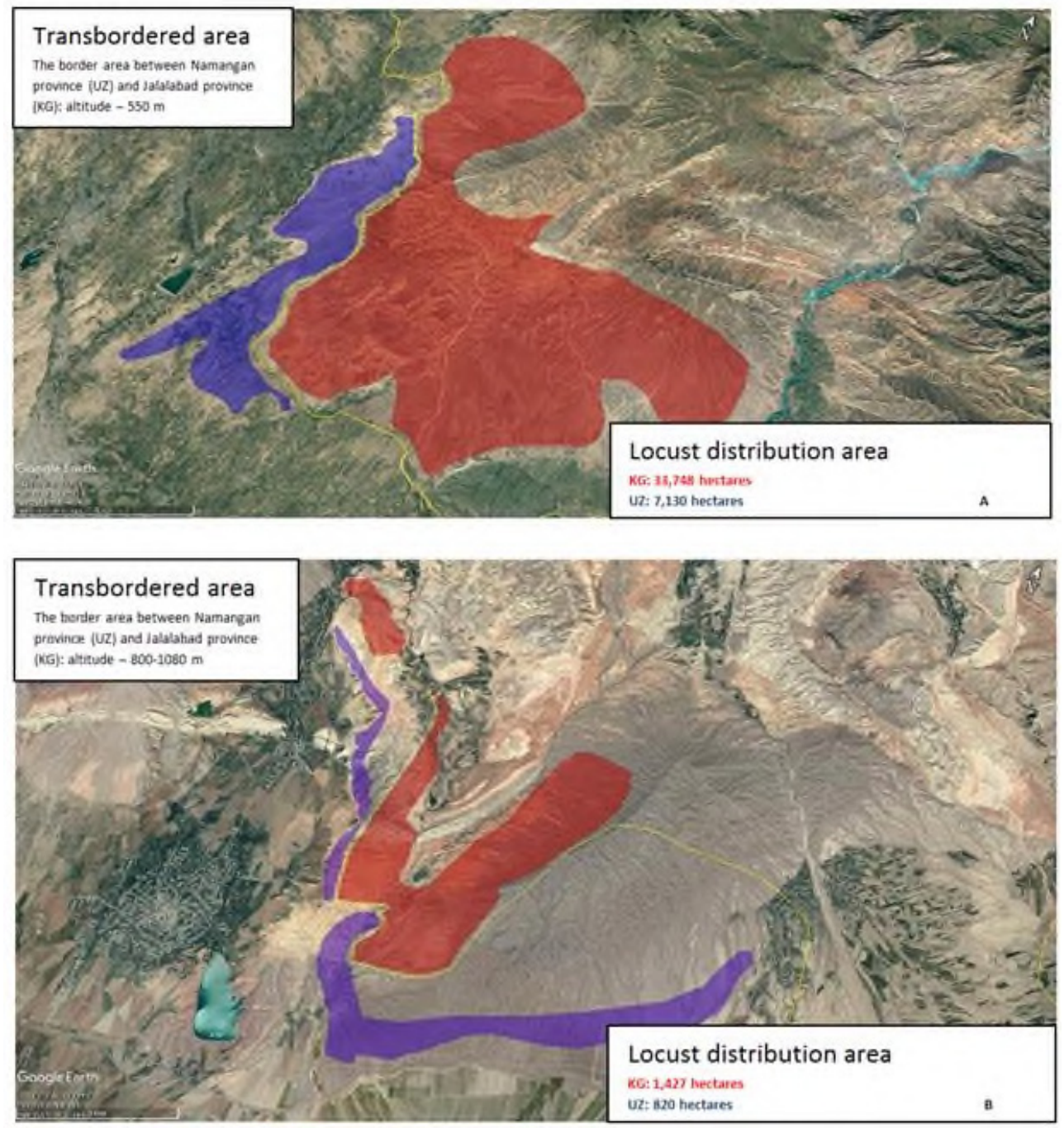

Fig. 4. Locust distribution areas in the border areas with Namangan province of the Republic of Kyrgyzstan and Jalalabad province of the Kyrgyz Republic (photo by GIS system of Google Earth).

\section{Conclusions}

According to the results of monitoring, the outbreaks of cross-border locusts in the border areas of the Republic with neighboring countries were identified on 186,674 hectares. In the territory of neighboring countries bordering on us, the outbreaks of harmful locusts were detected on 315,778 hectares, close to the border and the possibility of flight. Although the most probable locust infestation is in the border area of Jizzakh province with the Sughd province of the Republic of Tajikistan, the uneven location of the border area makes it difficult to control locusts in these areas. The largest areas of cross-border locust infestation are Surkhandarya and Khatlon provinces, and Kashkadarya and Lebap provinces.

Also in the transboundary areas Dociostaurus maroccanus Thunb - Morocco, Calliptamus italicus L - Italy, C turanicus Tarb (mountain), Locusta migratoria L - Asian 
locusts and rodents - Tettigonia viridissima $\mathrm{L}$ and $T$ caudata Charpanda require control of cross-border areas.

\section{References}

1. F. Gapparov, KH. Agzamova, A. Nurjanov, N. Tufliev, M. Medetov, F. Nurjonov, Plant Quarantine and Protection, 6, 28 (2013)

2. A. Monar, M. Shiris, Locust situation and locust control in the Caucasus and Central Asia - Research Report FAO, 82 (2009)

3. A. Nurjanov, R. Ruzmetov, I. Abdullaev, R. Eshchanov, B. Ramatov, M. Sultonov, F. Nurjonov, N. Abdalyazov, GIS against pests, 72 (2018)

4. R. Kulmatov, A. Taylakov, S. Khasanov, Environmental Science and Pollution Research, 28(10), 12245-12255 (2021)

5. S. Isaev, S. Khasanov, Y. Ashirov, T. Karabaeva, A. Gofirov, In E3S Web of Conferences, 244, 02012 (2021)

6. N. Tufliev, F. Nurjonov, J. of Agrochemistry and Plant Quarantine, 2, 39-40 (2020)

7. F. A. Gapparov, A. V. Latchininskiy, A. A. Nurzhanov, N. X. Tufliev, Metaleptea, 36(2), 17-19 (2016)

8. D. Hunter, A. Latchininskiy, E. Abashidze, F. Gapparov, A. Nurzhanov, M. Medetov,

N. Tufliev, Journal of Orthoptera Research, 25(2), 61-65 (2016)

9. R. Simanpillai, A. Latchininskiy, Entomologia Experimentalis et Applicata, 128(2), 346-353 (2008)

10. Z. Hao, V. Drake, L. Sidhu, J. Taylor, International journal of biometeorology, 61(12), 2073-2084 (2017)

11. C. Death, S. R. Griffiths, P. Story, Current Opinion in Environmental Science \& Health, 11, 43-52 (2019)

12. G. D. Martin, South African Journal of Botany, 125, 481-492 (2019)

13. I. Klein, N. Oppelt, C. Kuenzer, Insects, 12(3), 233 (2021)

14. K. Walden, Oilseeds update, 67 (2000)

15. I. Aslanov, S. Khasanov, Y. Khudaybergenov, M. Groll, Ch. Opp, F. Li, E. Ramirez Del-Valle, In E3S Web of Conferences, 227, 02005 (2021)

16. Y. Peng, F. Li, N. Xu, R. Kulmatov, K. Gao, G. Wang, Y. Zhang, Y. Qiao, Y. Li, H. Yang, S. Hao, Q. Li, S. Khasanov, Chinese Journal of Eco-Agriculture, 29(2), 312-324 (2021)

17. R. A. Kulmatov, S. A. Adilov, S. Khasanov, In IOP Conference Series: Earth and Environmental Science, 614(1), 012149 (2020)

18. B. Alikhanov, S. Alikhanova, R. Oymatov, Z. Fayzullaev, A. Pulatov, IOP Conference Series: Materials Science and Engineering, 883(1), 012088 (2020)

19. J. Gerts, M. Juliev, A. Pulatov, GeoScape, 14(1), 62-69 (2020)

20. C. Opp, M. Groll, I. Aslanov, T. Lotz, N. Vereshagina, Quaternary International, 429, 86-99 (2017) 